OPEN ACCESS

Edited by:

Robert Huber,

Bowling Green State University,

United States

Reviewed by:

Norma Andrea Velazquez Ulloa, Lewis \& Clark College, United States

Paul F. Morris,

Bowling Green State University, United States

*Correspondence: Michael Wink wink@uni-heidelberg.de

Specialty section:

This article was submitted to Invertebrate Physiology, a section of the journal Frontiers in Physiology

Received: 02 February 2018 Accepted: 26 March 2018

Published: 11 April 2018

Citation:

Wink M (2018) Plant Secondary

Metabolites Modulate Insect Behavior-Steps Toward Addiction? Front. Physiol. 9:364. doi: 10.3389/fphys.2018.00364

\section{Plant Secondary Metabolites Modulate Insect Behavior-Steps Toward Addiction?}

\author{
Michael Wink* \\ Institute of Pharmacy and Molecular Biotechnology, Heidelberg University, Heidelberg, Germany
}

Plants produce a diversity of secondary metabolites (PSMs) that serve as defense compounds against herbivores and microorganisms. In addition, some PSMs attract animals for pollination and seed dispersal. In case of pollinating insects, PSMs with colors or terpenoids with fragrant odors attract pollinators in the first place, but when they arrive at a flower, they are rewarded with nectar, so that the pollinators do not feed on flowers. In order to be effective as defense chemicals, PSMs evolved as bioactive substances, that can interfere with a large number of molecular targets in cells, tissues and organs of animals or of microbes. The known functions of PSMs are summarized in this review. A number of PSMs evolved as agonists or antagonists of neuronal signal transduction. Many of these PSMs are alkaloids. Several of them share structural similarities to neurotransmitters. Evidence for neuroactive and psychoactive PSMs in animals will be reviewed. Some of the neuroactive PSMs can cause addiction in humans and other vertrebrates. Why should a defense compound be addictive and thus attract more herbivores? Some insects are food specialists that can feed on plants that are normally toxic to other herbivores. These specialists can tolerate the toxins and many are stored in the insect body as acquired defense chemicals against predators. A special case are pyrrolizidine alkaloids (PAs) that are neurotoxic and mutagenic in vertebrates. PAs are actively sequestered by moths of the family Arctiidae and a few other groups of arthropods. In arctiids, PAs are not only used for defense, but also serve as morphogens for the induction of male coremata and as precursors for male pheromones. Caterpillars even feed on filter paper impregnated with pure PAs (that modulate serotonin receptors in vertebrates and maybe even in insects) and thus show of behavior with has similarities to addiction in vertebrates. Not only PA specialists, but also many monophagous herbivores select their host plants according to chemical cues i.e., PSMs) and crave for plants with a particular PSMs, again a similarity to addiction in vertebrates.

Keywords: plant secondary metabolites, pharmacology, toxicology, plant-insect interactions, neurotoxicity, psychoactive natural products 


\section{EVOLUTION AND FUNCTION OF PLANT SECONDARY METABOLITES ${ }^{1}$}

Since the early days of plant evolution in the Devonian period, plants had to cope with herbivores, but also with bacteria, fungi and viruses around them. Plants cannot run away when attacked by an herbivore, nor do they possess an adaptive immune system as present in vertebrates against microbial infections (Wink, 1988, 2003).

Similar to the situation of other immobile or slow-moving organisms (amphibians, slugs, cnidarians, and sponges) plants invested into the production of a wide diversity of organic compounds, the so-called secondary metabolites (PSMs). The structures of PSMs underwent several rounds of selection; thus their structures were shaped in such a way that they could interfere with the metabolism, neuronal transmission or reproduction of an herbivore or microbe. In consequence, nearly all PSMs exhibit some sort of biological activity and PSMs support plants to ward off herbivores and microbial infections (Wink, 1988, 2003). Plants also employ other strategies in this context, such as an impenetrable bark and cuticles, thorns, spikes and stinging hairs; furthermore, plants possess the capacity of open growth. Thus, they can renew parts that had been damaged by an herbivore.

Plants produce a substantial structural diversity of PSMs, such as alkaloids, amines, cyanogenic glucosides, glucosinolates, non-protein amino acids, organic acids, terpenoids, phenolics, quinones, polyacetylenes, and peptides. Over 100,000 individual structures have been elucidated already (Wink, 1988, 2003). Plants do not produce a single compound for defense, but usually a complex mixture of PSMs from different structural classes that can attack multiple molecular targets at the same time and often in a synergistic fashion (Wink, 2008, 2015; Mason and Singer, 2015). The composition of these mixtures is not fixed, but varies in terms of both concentration and composition. Thus, mixtures differ between organs, developmental stages and within populations. We had previously suggested that this variation is an important strategy to avoid the adaptation and resistance of herbivores and pathogens against the chemical defense. It is widely known from medicine, that treatment of bacteria or viruses with a single drug will give raise to resistant strains in a rather short time (e.g., antibiotic resistance).

PSMs evolved as an important line of defense, but some of them are further used for other purposes. Flowering plants often employ insects as pollinators, and also a few other arthropods and vertebrates. These pollinators are attracted to flowers by their color or smell; color is usually due to the production of flavonoids, anthocyanins, or carotenoids, whereas terpenoids, amines and phenylpropanoids exhibit distinctive odors that are recognized by pollinators (not necessarily by all animals).

\footnotetext{
${ }^{1}$ In this review, I often cite results from the research of myself or my co-workers. I am aware that many other scientists have also worked in this field and published thousands of scholarly papers, which could have been cited instead (apology to all colleagues, whom I did not cite). The review does not cover the complete literature that exists on this topic. If complete, the review would have been very long and outside the scope of the journal. Therefore, this invited article presents my personal and certainly limited view.
}

However, pollinators should be attracted to flowers but should not eat them. Thus, the attractant PSMs and other compounds are toxic and deterrent for a pollinator that tries to feed on flowers. Instead, flowers produce sugar-rich nectar as a reward for pollinating animals that they normally prefer over other flowering material (Wink, 1988, 2003; Detzel and Wink, 1993). Plants try to disperse their seeds beyond the direct neighborhood of the producing mother plants. Also in this context, animals are being manipulated as fruit-and seed dispersers. Mature fruits are usually sweet and show attractive colouration and smell. Fruit-eating animals (frugivores) are adapted to eat ripe fruits; but they do not destroy the seeds, that pass the intestinal tract without harm. Furthermore, as frugivores will deposit their faces far away from the fruiting tree, the seeds become dispersed and furthermore they are dropped together with potential fertilizers. Some PSMs also serve the producing plants directly as antioxidants, nitrogen storage compounds or for UV protection. Thus, most PSMs have multiple functions for a plant producing them (Wink, 1988, 2003).

A special case is the production of PSMs that interfere with the nervous system in animals. In vertebrates, several small-molecule neurotransmitters are known that modulate the activity of neuroreceptors (Wink, 2000). Among the most important neurotransmitters are acetylcholine, GABA, serotonin, dopamine, adrenaline, noradrenaline, adenosine, histamine, glutamate, and endorphins. Some of the PSMs that mimic the structure of neurotransmitters are CNS stimulants, others psychedelic and hallucinogenic (especially those binding to serotonin and dopamine receptors). Because herbivores that feed on psychoactive PSMs, often become addicted to the drugs, such compounds appear to be counterproductive, as they will attract herbivores. However, in the wild, the survival of an intoxicated herbivore is probably quite short. It will either fall from trees and rocks or will be an easy prey for the predators which are abundant in most ecosystems.

\section{PHARMACOLOGY AND TOXICOLOGY OF PLANT SECONDARY METABOLITES}

Among alkaloids, several modulate neuronal signal transduction and are thus often toxic for herbivores. Ion channels, neurotransmitter receptors, neurotransmitter inactivating enzymes and transporters play an important role. Examples for alkaloids, known to interfere with these targets (mostly in vertebrates) are documented in Table 1.

When PSMs modulate elements of neuronal signal transduction, the concentrations of neurotransmitters, the activity of neurotransmitter receptors or their expression can be changed. This can lead to severe changes in physiology and often in the behavior of an animal. Addiction can be one of them.

Many PSMs can modulate the bioactivity and/or 3D structure of proteins. Among them are some specific inhibitors (such as colchicine, inhibiting microtubule assembly). The majority of the widely distributed phenolic compounds can modulate the $3 \mathrm{D}$ structure of proteins by forming multiple hydrogen and ionic bonds with them (Table 2; Wink, 2008, 2015). In addition, some 
TABLE 1 | Examples for alkaloids and other PSMs that modulate neuronal signal transduction (more details in Wink, 2000; Wink and Schimmer, 2010).

\begin{tabular}{|c|c|c|}
\hline Target & Alkaloids & Activity \\
\hline \multicolumn{3}{|c|}{ ION CHANNELS } \\
\hline & Aconitine & Agonist \\
\hline & Ajmaline & Antagonist \\
\hline & Berbamine & Antagonist \\
\hline & Capsaicin & antagonist \\
\hline & Cocaine & Antagonist \\
\hline & Dicentrine & Antagonist \\
\hline & Ervatamine & Antagonist \\
\hline & Glaucine & Antagonist \\
\hline & Hirsutine & Antagonist \\
\hline & Liriodenine & Antagonist \\
\hline & Paspaline & Antagonist \\
\hline & Phalloidin & antagonist \\
\hline & Quinidine & Antagonist \\
\hline & Ryanodine & Agonist \\
\hline & Sparteine & Antagonist \\
\hline & Strychnine & Antagonist \\
\hline & Veratrine & Agonist \\
\hline & Vincamine & Antagonist \\
\hline & Zygademine & Agonist \\
\hline \multicolumn{3}{|c|}{ NEUROTRANSMITTER RECEPTORS } \\
\hline \multicolumn{3}{|c|}{ Nicotinic acetylcholine receptor (nAChR) } \\
\hline & Anabasine & Agonist \\
\hline & Boldine & Antagonist \\
\hline & Coniine & Agonist \\
\hline & Cytisine, lupanine & Agonist \\
\hline & Erythrina alkaloids & Antagonist \\
\hline & Methyllycaconitine & Antagonist \\
\hline & Nicotine & Agonist \\
\hline & Tubocurarine & Antagonist \\
\hline
\end{tabular}

Muscarinic acetylcholine receptor (mAChR) (GPCR)

\begin{tabular}{ll}
\hline Arecoline & Agonist \\
Cryptolepine & Agonist \\
Ebeinone & Antagonist \\
Himbacine & Antagonist \\
Hyoscyamine, & Antagonist \\
scopolamine & \\
Muscarine & Agonist \\
Pilocarpine & Agonist \\
Sparteine & agonist \\
\hline Dopamine receptor (GPCR) & \\
\hline Agroclavine & Agonist \\
Eulbocapnine & Antagonist \\
Ergot alkaloids & Agonist \\
Loline & Agonist \\
& Agonist \\
\end{tabular}

(Continued)
TABLE 1 | Continued

\begin{tabular}{lll}
\hline Target & Alkaloids & Activity \\
\hline & Salsolinol & Agonist \\
Tyramine & Antagonist
\end{tabular}

Serotonin receptor (mostly GPCR)

\begin{tabular}{ll}
\hline Akuammine & Antagonist \\
Bufotenine & Agonist \\
Confusameline & antagonist \\
Ergot alkaloids & Antagonist \\
Harman and other & Agonist \\
harmine alkaloids & \\
Liridinine & Antagonist \\
Mescaline & Agonist \\
Mitragynine & Agonist \\
N-Methyltryptamine & Agonist \\
Psilocine & Agonist
\end{tabular}

Adenosine receptor (GPCR)

Caffeine, theobromine, Antagonist
theophylline

GABA receptor (mostly ICR)

\begin{tabular}{ll}
\hline Bicuculline & Antagonist \\
Corlumine & Antagonist \\
Hydrastine & Antagonist \\
Muscimol & Agonist \\
Securinine & Antagonist
\end{tabular}

Glutamate receptor (mostly ICR)

\begin{tabular}{ll}
\hline Acromelic acid & Agonist \\
Domoic acid & Agonist \\
Ibogaine & Antagonist \\
Ibotenic acid & Agonist \\
Kainic acid & Agonist \\
Nuciferine & Antagonist \\
Quisqualic acid & Agonist \\
Willardiine & Agonist \\
\hline
\end{tabular}

Noradrenaline receptor (GPCR)

$\begin{array}{ll}\text { Ajmalicine } & \text { Antagonist } \\ \text { Berbamine } & \text { Antagonist } \\ \text { Berberine } & \text { Antagonist } \\ \text { Boldine } & \text { Antagonist } \\ \text { Bulbocapnine } & \text { Antagonist } \\ \text { Corynanthine } & \text { Antagonist } \\ \text { Crebanine } & \text { Antagonist } \\ \text { Dispegatrine } & \text { Antagonist } \\ \text { Ergot alkaloids } & \text { Agonist / antagonists } \\ \text { Glaucine } & \text { Antagonist } \\ \text { Octopamine } & \text { Agonist } \\ \text { Predicentrine } & \text { Antagonist }\end{array}$

(Continued) 
TABLE 1 | Continued

\begin{tabular}{|c|c|c|}
\hline Target & Alkaloids & Activity \\
\hline & Yohimbine & Antagonist \\
\hline \multicolumn{3}{|c|}{ Endorphine receptor (GPCR) } \\
\hline & Akuammine & Agonist \\
\hline & lbogaine & Agonist \\
\hline & Mitragynine & Agonist \\
\hline & Morphine & Agonist \\
\hline \multicolumn{3}{|c|}{ INACTIVATION OF NEUROTRANSMITTERS } \\
\hline \multicolumn{3}{|c|}{ Acetylcholine esterase } \\
\hline & Berberine & Antagonist \\
\hline & Galantamine & Antagonist \\
\hline & Harmaline & Antagonist \\
\hline & Huperzine & Antagonist \\
\hline & Physostigmine & Antagonist \\
\hline & Sanguinarine & Antagonist \\
\hline & Solanum alkaloids & Antagonist \\
\hline & Vasicinol & Antagonist \\
\hline
\end{tabular}

Monoamine oxidase (MAO)

\begin{tabular}{|c|c|}
\hline Alstovenine & Antagonist \\
\hline Carnegine & Antagonist \\
\hline $\begin{array}{l}\text { N,N- } \\
\text { dimethyltryptamine }\end{array}$ & Antagonist \\
\hline $\begin{array}{l}\text { Harmaline and other } \\
\text { harman alkaloids }\end{array}$ & Antagonist \\
\hline Saracodine & Antagonist \\
\hline Salsolidine & Antagonist \\
\hline \multicolumn{2}{|c|}{ TRANSPORTER FOR NEUROTRANSMITTERS } \\
\hline Annonaine & Inhibition of DA reuptake \\
\hline Arecaidine & Inhibition of GABA reuptake \\
\hline Cocaine & Inhibition of DA uptake \\
\hline Ephedrine & $\begin{array}{l}\text { Release of NA from synaptic } \\
\text { vesicles; inhibition of NA } \\
\text { reuptake }\end{array}$ \\
\hline Ibogaine & $\begin{array}{l}\text { Modulates DA, NA and } \\
5-H T \text { transporters in } \\
\text { synaptic vesicles }\end{array}$ \\
\hline Norharman & $\begin{array}{l}\text { Inhibitor of DA and } \\
\text { tryptamine uptake }\end{array}$ \\
\hline Reserpine & $\begin{array}{l}\text { Depletes stores of NA and } \\
5-\mathrm{HT} \text { in synaptic vesicles }\end{array}$ \\
\hline Salsolinol & $\begin{array}{l}\text { Inhibitor for uptake of } \\
\text { biogenic amine } \\
\text { neurotransmitters }\end{array}$ \\
\hline Veratramine & $\begin{array}{l}\text { Releaser and uptake } \\
\text { inhibitor for } 5-\mathrm{HT}\end{array}$ \\
\hline
\end{tabular}

\section{ION PUMPS}

$\mathrm{Na}^{+} / \mathrm{K}^{+}$-ATPase

Ouabain and other

Inhibitor

cardiac glycosides

In case of neurotransmitter receptors, some are ion channel coupled receptors (nAChR, 5HT3, NMDA, AMPA, kainate, GABAA) (=ICR), the other metabotropic receptors coupled with G-protein (GPCR)
TABLE 2 | PSMs interfering with proteins (more details in Wink, 2008, 2015; Wink and Schimmer, 2010).

\begin{tabular}{|c|c|c|c|}
\hline Activity & PSMs & Examples & Comments \\
\hline \multicolumn{4}{|c|}{ COVALENT BONDS WITH PROTEINS } \\
\hline With SH-groups & With SH groups & $\begin{array}{l}\text { Allicin and similar } \\
\text { PSMs }\end{array}$ & \\
\hline \multirow[t]{2}{*}{$\begin{array}{l}\text { With amino } \\
\text { groups }\end{array}$} & $\begin{array}{l}\text { With epoxy } \\
\text { groups }\end{array}$ & & \\
\hline & $\begin{array}{l}\text { With exocyclic } \\
\text { methylene } \\
\text { groups }\end{array}$ & $\begin{array}{l}\text { Sesquiterpene } \\
\text { lactones }\end{array}$ & \\
\hline \multirow{3}{*}{$\begin{array}{l}\text { Non-covalent } \\
\text { bonding with } \\
\text { proteins }\end{array}$} & $\begin{array}{l}\text { With amino } \\
\text { groups }\end{array}$ & $\begin{array}{l}\text { Phenolics, } \\
\text { polyphenols }\end{array}$ & $\begin{array}{l}\text { Hydrogen and } \\
\text { ionic bonds }\end{array}$ \\
\hline & $\begin{array}{l}\text { With hydroxyl } \\
\text { groups }\end{array}$ & $\begin{array}{l}\text { Phenolics, } \\
\text { polyphenols }\end{array}$ & $\begin{array}{l}\text { Hydrogen and } \\
\text { ionic bonds }\end{array}$ \\
\hline & $\begin{array}{l}\text { With lipophilic } \\
\text { sites }\end{array}$ & $\begin{array}{l}\text { Lipophilic } \\
\text { terpenes }\end{array}$ & $\begin{array}{l}\text { Hydrophobic } \\
\text { attraction }\end{array}$ \\
\hline
\end{tabular}

PSMs possess chemically reactive functional groups by which they can form covalent bonds with amino, sulfhydryl or hydroxyl groups of amino acid residues of proteins (Table 2). Lipophilic terpenes can assemble in the inner hydrophobic core of globular proteins that thus can change their $3 \mathrm{D}$ structures.

A special case of protein inhibitors are those which can interfere with protein synthesis in ribosomes, such as lectins (e.g., ricine, abrine), emetine, and lycorine (Wink and Schimmer, 2010; Wink, 2015).

Biomembranes that surround all living cells and intracellular compartments, are the target for lipophilic PSMs (Table 3). They can be trapped inside the biomembrane and thus change its fluidity and permeability. Typical lipophilic PSMs include mono-, sesqui-, di-, and triterpenes, steroids, mustards oils, and phenylpropanoids. A special case are saponins that consist of a lipophilic steroid or triterpene moiety and a hydrophilic sugar chain. These compounds are amphiphilic and can lyse biomembrane by complexing membrane cholesterol (Table 3 ). Also antimicrobial peptides (AMPs) that are part of the innate immune system of most organisms, interfere with biomembranes of microbes but also of eukaryotic cells.

Several PSMs can interfere with nucleic acid and enzymes that metabolize them (Wink and Schimmer, 2010). We can distinguish between DNA intercalating and DNA alkylating compounds (Table 4). Lipophilic, aromatic and planar PSMs (such as furanocoumarins, berberine, sanguinarine) can intercalate between the stacks of DNA-base pairs. Intercalators stabilize DNA and can prevent the activity of helicases and RNA polymerases; they can be mutagenic (because of frame shift), genotoxic, and cytotoxic (Table 4). Alkylating agents directly bind to nucleotide bases and form covalent bonds. They also lead to mutations and genotoxicity (Table 4).

\section{PLANT-INSECT INTERACTIONS}

Among all multicellular living organisms, plants and insects exhibit the largest diversity with more than 1 million described 
arthropod taxa (mostly insects) and more than 350,000 plant taxa. Amongst eukaryotes, the diversity of plants and metazoans pales in comparison to the diversity amongst fungal taxa (albeit non-described so far; Yahr et al., 2016). Although flowering plants (angiosperms) evolved already during the Cretaceous, an extensive radiation took place at the start of the Tertiary, 66 million years ago. Evidence suggests that parallel to the angiosperm radiation, a radiation of insects set in as well. If both radiations were true co-evolutionary processes is an open debate. Many insects are pollinators, others are herbivorous. Among the herbivores, we can distinguish polyphagous species that feed on many plant species, oligophagous species that love a selection of plants and monophagous species that are adapted to individual species or species groups which produce similar PSMs (Ali and Agrawal, 2012; Mason and Singer, 2015).

The herbivorous insects had and still have to cope with the PSMs in their food plants (Detzel and Wink, 1993; Linde and Wittstock, 2011). They have evolved several mechanisms to tolerate or detoxify PSMs. Mostly, the generalists have very active enzymes that either inactivate (via CYP) or quickly eliminate

TABLE 3 | PSMs interfering with biomembranes (more details in Wink, 2008, 2015; Wink and Schimmer, 2010).

\begin{tabular}{llll}
\hline Activity & PSMs & Examples & Comments \\
\hline $\begin{array}{l}\text { Increasing } \\
\text { membrane } \\
\text { fluidity }\end{array}$ & $\begin{array}{l}\text { Lipophilic } \\
\text { terpenoids }\end{array}$ & $\begin{array}{l}\text { Monoterpene, } \\
\text { sesquiterpenes }\end{array}$ & $\begin{array}{l}\text { Membranes } \\
\text { become leaky or } \\
\text { disintegrate }\end{array}$ \\
$\begin{array}{l}\text { Lysis of } \\
\text { membranes }\end{array}$ & $\begin{array}{l}\text { Triterpene and } \\
\text { steroidal } \\
\text { saponins }\end{array}$ & & $\begin{array}{l}\text { Saponins bind to } \\
\text { membrane } \\
\text { cholesterol and } \\
\text { induce cell lysis }\end{array}$ \\
& AMPs & Widely & $\begin{array}{l}\text { Part of the innate } \\
\text { immune system }\end{array}$
\end{tabular}

(via $\mathrm{ABC}$ transporter) toxic PSMs. Another strategy is to feed not only on one plant, but to sample from several species (with low PSMs content) thus diluting any toxic effect. Often herbivores have a fast digestion, by which they absorb nutrients quicker than any toxins that are quickly eliminated in the feces. For detoxification, some herbivores obtain help from symbiotic intestinal microorganisms that often can degrade or inactivate toxic material (Pennisi, 2017).

From a plant side of view, the specialists have won the evolutionary arms race. They can harm their host plants severely if their numbers are large. This can be seen in areas where Senecio jacobaea plants (producing PAs) are abundant. If the PA specialist moth Tyria jacobaeae occurs in the same area, a Senecio population may suffer seriously. But even under these conditions Tyria will not completely wipe out its host plants (Wink and Legal, 2001). A predator-prey equilibrium will emerge in the long run.

\section{UTILIZATION OF PLANT SECONDARY METABOLITES BY INSECTS}

Among monophagous insects, several specialists have been described that apparently love their toxic host plants. These specialists often not only tolerate the toxic PSMs of the host plant, but actively sequester them in their body (Wink, 1992, 1993; Brown and Trigo, 1995; Hartmann and Witte, 1995; Hartmann, 1999, 2004; Petschenka and Agrawal, 2016). Thus, these specialists can store substantial amounts of toxic PSMs and use them for their own defense against predators (Mason and Singer, 2015). Such specialist have been described for toxic cardiac glycosides, aristolochic acids, cyanogenic glucosides, iridoid glucosides and several toxic alkaloids (aconitine, pyrrolizidines, quinolizidines) (Wink, 1992, 1993; Sime et al., 2000; Dobler, 2001; Zagrobelny and Møller, 2011; Kelly and Bowers, 2016;

TABLE 4 | Examples for PSMs interfering with nucleic acids (DNA, RNA) (more details in Wink, 2008, 2015; Wink and Schimmer, 2010).

\begin{tabular}{|c|c|c|c|}
\hline Target & PSMs & Activity & Comments \\
\hline \multicolumn{4}{|c|}{ DNA INTERCALATION } \\
\hline & Berbamine & Strong intercalator & Also inhibition of replication and ribosomal protein biosynthesis \\
\hline & Berberine & Strong intercalator & Also inhibition of replication and ribosomal protein biosynthesis \\
\hline & Dictamnine and other furaquinoline alkaloids & Strong intercalator & After UV activation also DNA alkylation \\
\hline & Ellipticine & Strong intercalator & \\
\hline & Harmine and other Harman alkaloids & Strong intercalator & Also inhibition of replication and ribosomal protein biosynthesis \\
\hline & Psoralen and other furanocoumarins & Strong intercalator & After UV activation also DNA alkylation \\
\hline & Rutacridone and other acridone alkaloids & Strong intercalator & After UV activation also DNA alkylation \\
\hline & Sanguinarine & Strong intercalator & Also inhibition of replication and ribosomal protein biosynthesis \\
\hline \multicolumn{4}{|c|}{ DNA ALKYLATION } \\
\hline & Aristolochic acid & Mutagenic after metabolic activation & \\
\hline & Cycasin & Methylazooxymethanol is the active mutagen & \\
\hline & Furanoquinoline alkaloids & Mutagenic after metabolic activation & \\
\hline & Ptaquiloside & Active after removal of glucose from glycoside & \\
\hline & Safrole and other phenylpropanoids & Mutagenic after metabolic activation & \\
\hline & Senecionine and other PAs & Mutagenic after metabolic activation & \\
\hline
\end{tabular}


Petschenka and Agrawal, 2016). These specialist often exhibit warning colors, i.e., they are aposematic; and thus advertise their potential toxicity to any predator.

In most instances, we do not know how these specialists circumvent the inherent toxicity of PSMs. For some insects that sequester cardiac glycosides, it could be shown, that the binding site of their molecular target, the $\mathrm{Na}^{+}, \mathrm{K}^{+}$-ATPase, has been changed through point mutations in such a way, that cardiac glycosides no longer bind to it. Thus, Monarch butterflies can tolerate high concentrations of cardiac glycosides that would kill any poly- or oligophagous species (Holzinger et al., 1992; Holzinger and Wink, 1996; Dobler et al., 2012; Aardema and Andolfatto, 2016). In most other cases, we do not have a clear evidence, how an insensitivity has been accomplished.

\section{ADDICTION OF INSECTS TO PLANT CHEMISTRY?}

As mentioned above, monophagous species [mostly butterflies and moths, aphids and other hemipterans) only feed on a single particular plant species that produces a certain kind of toxin, such as cardiac glycosides, iridoid glycosides, glucosinolates, cyanogenic glucosides, or alkaloids [pyrrolizidine (PA), quinolizidine alkaloids (QA)] (Boppré, 1984; Wink, 1992, 1993; Brown and Trigo, 1995; Hartmann and Witte, 1995; Hartmann, 1999, 2004; Klitzke and Trigo, 2000; Laurent et al., 2005; Hilker and Meiners, 2011; Macel, 2011; Trigo, 2011; Cogni et al., 2012). If related plants produce similar toxins, such as in Brassica species that all produce glucosinolates, then even a monophagous species may feed on more than a single host plant because they love these particular PSMs. But they will not live on plants with different kinds of PSMs.

Who decides on the choice of a food plant? In most instances, it will be the female with fertile eggs that will search for its specific food plants that it can identify because of their typical PSMs profile. In case of plants from the family Brassicaceae that all produce glucosinolates (which release the often odorant mustard oils), it has been shown that the mustard oils guide a butterfly to its appropriate host plant (Renwick and Lopez, 1999). Apparently, specific odorant receptors have evolved in such butterflies (like Garden Whites, Pieridae) that are activated if the odorant from cabbage plants pass along their antennae. In this instance, the plant odorant appears to work like the pheromones that are used by insects to attract potential mates. Food consumption by larvae of Pieris rapae that love food plant with glucosinolates, has been compared with addiction in vertebrates (Renwick and Lopez, 1999).

A similar situation has been described from arctiid moths with sequester PAs, such as Utetheisa and Creatonotus. We have studied PAs in Creatonotus for several years in collaboration with Dietrich Schneider, who had discovered the strange relationship between moths and PAs (Boppré, 1986; Wink and Schneider, 1988, 1990; von Nickisch-Rosenegk et al., 1990; von Nickisch-Rosenegk and Wink, 1993). The caterpillars can be reared on artificial diets without PAs. But the hairy caterpillars of Creatonotus gangis and C. transiens clearly prefer any plant that produces PAs. Plants with other toxic alkaloids are usually avoided. The larvae appear to be addicted to PAs, because they will even chew filter paper that was impregnated with pure PAs. Normally, they would never touch filter paper, even when hungry. This indicates that PAs induce a very strong feeding stimulus, similar to the situation of the behavior of humans toward addictive drugs.

Addiction in humans implies a craving for a certain chemical whose consumption would confer happiness, good feeling or hallucinations. Addiction will change the personality of the consumer as a strong urge appears once the level of the addictive chemical has dropped in the body.

PAs are actively absorbed by the larvae: PAs mostly occur as polar PA N-oxides which cannot pass biomembranes by simple diffusion. There is evidence that transporter proteins exist at the gut epithelium that can transport the polar alkaloids into the haemolymph (Wink and Schneider, 1988). An alternative mechanism was also found, in that PA become reduced to the more lipophilic free base in the gut which can pass the membranes by simple diffusion. Once the alkaloids have reached the haemolymph, they will be re-oxidized to PA N-oxides (Wang et al., 2012). The PAs do not stay in the haemolymph, but are sequestered into the integument of the larvae (Egelhaaf et al., 1990; von Nickisch-Rosenegk et al., 1990; Wink et al., 1990; von Nickisch-Rosenegk and Wink, 1993), where they serve as defense compounds against predators (Martins et al., 2015).

However, the situation becomes more complex if we look closer into male and female larvae after metamorphosis into adult insects: In female larvae, PAs will be sequestered to some degree in the integument, but a large part is transferred to the orange colored eggs that thus gain chemical protection (von NickischRosenegk et al., 1990). PAs as a nuptial gift for the defense of the eggs has also been described for other arctiids Utetheisa ornatrix and Cosmosoma myrodora (González et al., 1999; Conner et al., 2000; Bezzerides and Eisner, 2002; Cogni et al., 2012).

Males produce impressive coremata (these are inflatable sacks at the abdomen which are covered with many hairs) that are inflated during courtship and which will dissipate pheromones to attract female partners (Figure 1). Dietary PAs serve as a morphogen that induces the formation of coremata. If a caterpillar did not obtain PAs, then only very small coremata will develop in the imagines (Figure 1; Schneider et al., 1982; Boppré, 1986). Thus, the more PAs were ingested, the bigger the corema (von Nickisch-Rosenegk et al., 1990). It seems that co-evolution proceeded even a step further in this system (Schneider, 1992). The pheromones that are dissipated via the coremata, consist of hydroxydanadial (and others) that is derived from dietary PAs (Boppré, 1986; Wink et al., 1988; Schulz et al., 1993; Schulz, 1998). And evidence shows that female moths like males with an abundant PA perfume. And for good reason: we detected that the male spermatophore was also filled with dietary PAs that were transferred as a nuptial gift during copulation to the female increasing the PA contents of the eggs. Thus, males can contribute to the fitness of their offspring. Hydroxydanaidal that is produced by many PA plants is also a signal for other PA insects (Bogner and Boppré, 1989). However, arctiid caterpillars have 

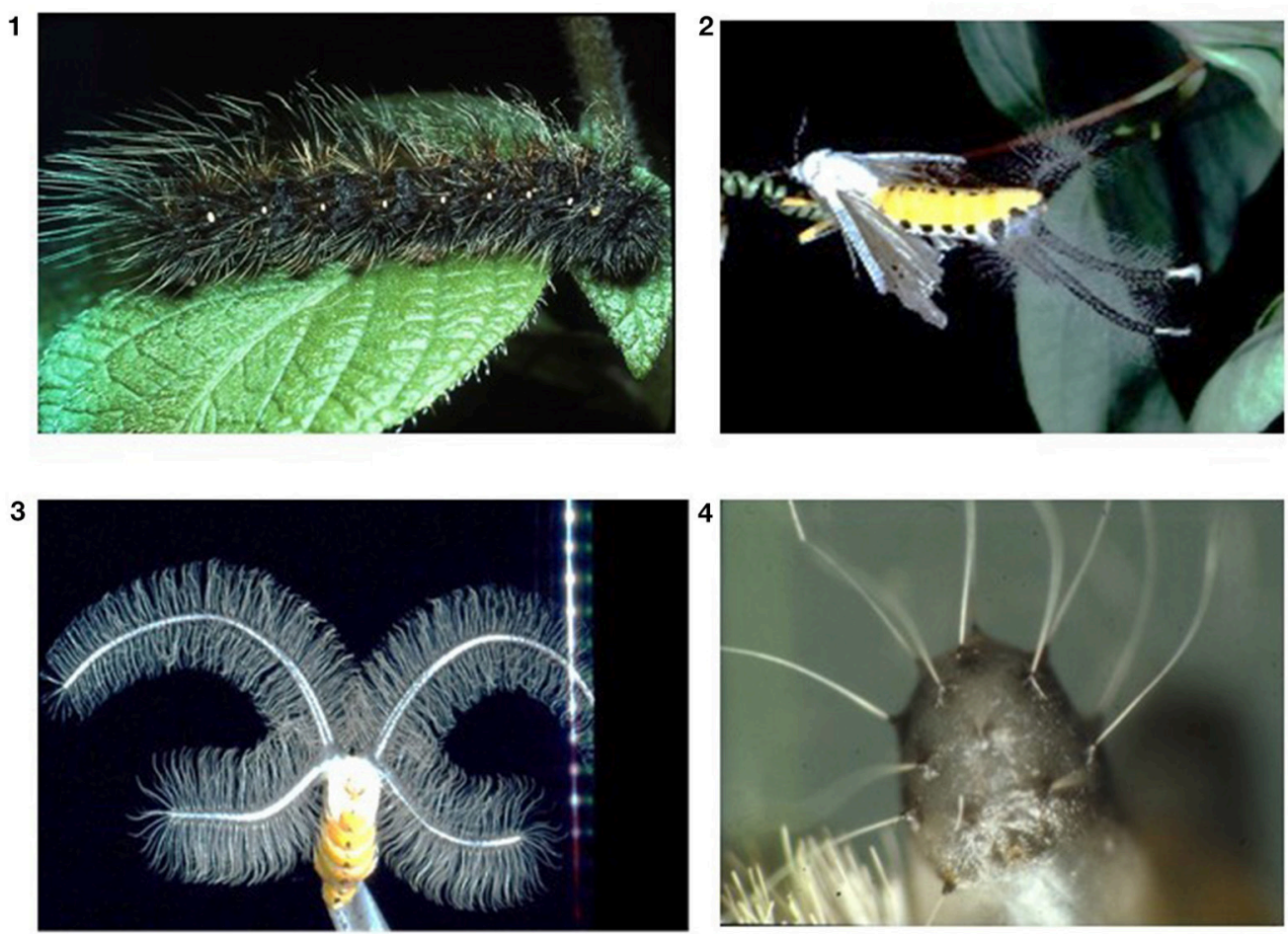

FIGURE 1 | Influence of PAs on the development of male corema in Creatonotos transiens. (1) Caterpillar, (2) Adult male with inflated corema, (3) Large corema of a male whose larva had PA-rich food, (4) Minute corema of a male whose larva had no PAs in its food.

taste receptor neurons which are dedicated to the perception of PAs and PA-N oxides (Bernays et al., 2002, 2003).

As shown in Table 1, many PSMs modulate the activity of neuroreceptors in vertebrates; what about insects? Insects have similar neurotransmitters, such as acetylcholine, GABA, glutamate, histamine, tyramine, dopamine, octopamine, and serotonin (Vleugels et al., 2015) indicating that neuroreception and corresponding mechanisms are evolutionary old features. Octopamine in insects is similar to noradrenaline in mammals (Vleugels et al., 2015). It is likely, that at least some of the PSMs listed in Table 1 as modulators of neuroreceptor activity for vertebrates, will also work on insect neuroreceptors. For example, there is evidence that insects lose their coordination when exposed to cocaine that binds to octopamine receptors. Serotonin receptors are expressed in the brain but also in the intestinal tract of animals. Serotonin is involved in the regulation of appetite, mood and emotion, sleep, sexual activity, pain, learning and memory (Vleugels et al., 2015). As serotonin agonist often induce euphoria and hallucinations in vertebrates, we can only speculate that maybe also insects react to serotonin receptor agonists (Vleugels et al., 2015). In vertebrates, PA bind to serotonin receptors (Schmeller et al., 1997). We do not know if this is also the case of serotonin receptors of insects that are also involved in the regulation of feeding, food choice and sleep (Vleugels et al., 2015). The addictive behavior of arctiid moths toward PAs, described above, would be plausible if this would be the case. This is an open question that needs to be addressed experimentally.

\section{CONCLUSIONS}

Many PSMs interfere with neuroreceptors and neurotransmitters in vertebrates (Wink, 2000; Wink and Schimmer, 2010). Since neuroreception is on old evolutionary invention, insects share many neuroreceptors with vertebrates, but have tyramine and octopamine receptors in addition (Schneider, 1992; Vleugels et al., 2015). Many insects feed on a single or a few often phylogenetically related food plants. It has been demonstrated, that PSMs serve as olfactory cues for insects to identify their appropriate food plants (Brown and Trigo, 1995). The behavior of insects toward such chemical cues reminds of drug addiction in humans and other vertebrates. It is a challenge for physiologist to discover how PSMs modulate neuroreception, and thus food choice. Since many psychoactive PSMs affect the serotoninergic and dopaminergic system in vertebrates (Table 1), it would be worth studying their effects on insects and find out if they also trigger addiction and behavioral changes in invertebrates. There is good evidence for cocaine and nicotine that these alkaloids are active in this context (Barron et al., 2009; Baracchi et al., 2017). 


\section{AUTHOR CONTRIBUTIONS}

The author confirms being the sole contributor of this work and approved it for publication.

\section{REFERENCES}

Aardema, M. L., and Andolfatto, P. (2016). Phylogenetic incongruence and evolutionary origins of cardenolide-resistant forms of $\mathrm{Na}^{+}, \mathrm{K}^{+}$-ATPase in Danaus butterflies. Evolution 70, 1913-1921. doi: 10.1111/evo.12999

Ali, J. G., and Agrawal, A. A. (2012). Specialist versus generalist insect herbivores and plant defense. Trends Plant Sci. 17, 292-302. doi: 10.1016/j.tplants.2012.02.006

Baracchi, D., Marples, A., Jenkins, A. J., Leitch, A. R., and Chittka, L. (2017). Nicotine in floral nectar pharmacologically influences bumblebee learning of floral features. Sci. Rep. 7:1951. doi: 10.1038/s41598-017-01980-1

Barron, A. B., Maleszka, R., Helliwell, P. G., and Robinson, G. E. (2009). Effects of cocaine on honey bee dance behaviour. J. Exp. Biol. 212, 163-168. doi: $10.1242 /$ jeb.025361

Bernays, E. A., Chapman, R. F., and Hartmann, T. (2002). A taste receptor neurone dedicated to the perception of pyrrolizidine alkaloids in the medial galeal sensillium of two polyphagous arctiid caterpillars. Physiol. Entomol. 27, 312-321. doi: 10.1046/j.1365-3032.2002.00304.x

Bernays, E. A., Chapman, R. F., Lamunyon, C. W., and Hartmann, T. (2003). Taste receptors for pyrrolizidine alkaloids in a monophagous caterpillar. J. Chem. Ecol. 29, 1709-1722. doi: 10.1023/A:1024239201198

Bezzerides, A., and Eisner, T. (2002). Apportionment of nuptial alkaloidal gifts by a multiply-mated female moth (Utetheisa ornatrix): eggs individually receive alkaloids from more than one male source. Chemoecology 12, 213-218. doi: 10.1007/PL00012671

Bogner, F., and Boppré, M. (1989). Single cell recordings reveal hydroxydanaidal as the volatile compound attracting insects to pyrrolizidine alkaloids. Entomol. Exp. Appl. 50, 171-184. doi: 10.1111/j.1570-7458.1989. tb02386.x

Boppré, M. (1984). Redefining “pharmacophagy.” J. Chem. Ecol. 10, 1151-1154.

Boppré, M. (1986). Insects pharmacophagously utilising defensive plant chemicals (pyrrolizidine alkaloids). Naturwissenschaften 73,17-26. doi: $10.1007 / \mathrm{BF} 01168801$

Brown, K. S., and Trigo, J. R. (1995). "The ecological activity of alkaloids," in The Alkaloids, Vol. 47, ed G. A. Cordell (New York, NY: Academic Press), 227-356.

Cogni, R., Trigo, J. R., and Futuyma, D. J. (2012). A free lunch? No cost for acquiring defensive plant pyrrolizidine alkaloids in a specialist arctiid moth (Utetheisa ornatrix). Mol. Ecol. 21, 6152-6162. doi: 10.1111/mec.12086

Conner, W. E., Boada, R., Schroeder, F. C., González, A., Meinwald, J., and Eisner, T. (2000). Chemical defense: bestowal of a nuptial alkaloidal garment by a male moth on its mate. Proc. Natl. Acad. Sci. U.S.A. 97, 14406-14411. doi: $10.1073 /$ pnas. 260503797

Detzel, A., and Wink, M. (1993). Attraction, deterrence or intoxication of bees (Apis mellifera) by plant allelochemicals. Chemoecology 4, 8-18. doi: $10.1007 / \mathrm{BF} 01245891$

Dobler, S. (2001). Evolutionary aspects of defense by recycled plant compounds in herbivorous insects. Basic Appl. Ecol. 2, 15-26. doi: 10.1078/1439-1791-00032

Dobler, S., Dalla, S., Wagschal, V., and Agrawal, A. A. (2012). Community-wide convergent evolution in insect adaptation to toxic cardenolides by substitutions in the Na,K-ATPase. Proc. Natl. Acad. Sci. U.S.A. 109, 13040-13045. doi: 10.1073/pnas.1202111109

Egelhaaf, A., Cölln, K., Schmitz, B., Buck, M., Wink, M., and Schneider, D. (1990). Organ specific storage of dietary pyrrolizidine alkaloids in the arctiid moth Creatonotos transiens. J. Biosci. 45, 115-120.

González, A., Rossini, C., Eisner, M., and Eisner, T. (1999). Sexually transmitted chemical defense in a moth (Utetheisa ornatrix). Proc. Natl. Acad. Sci. U.S.A. 96, 5570-5574. doi: 10.1073/pnas.96.10.5570

Hartmann, T. (1999). Chemical ecology of pyrrolizidine alkaloids. Planta 207, 483-495. doi: $10.1007 /$ s004250050508

\section{FUNDING}

This work was funded by grants of the Deutsche Forschungsgemeinschaft (DFG).

Hartmann, T. (2004). Plant-derived secondary metabolites as defensive chemicals in herbivorous insects: a case study in chemical ecology. Planta 219, 1-4. doi: 10.1007/s00425-004-1249-y

Hartmann, T., and Witte, L. (1995). "Chemistry, biology and chemoecology of the pyrrolizidine alkaloids," in Alkaloids: Chemical and Biological Perspectives, Vol. 9, ed S. W. Pelletier (Amsterdam: Elsevier), 155-233.

Hilker, M., and Meiners, T. (2011). Plants and insect eggs: How do they affect each other? Phytochemistry 72, 1612-1623. doi: 10.1016/j.phytochem.2011.02.018

Holzinger, F., Frick, C., and Wink, M. (1992). Molecular base for the insensitivity of the Monarch (Danaus plexippus) to cardiac glycosides. FEBS Lett. 314, 477-480.

Holzinger, F., and Wink, M. (1996). Mediation of cardiac glycoside insensitivity in the monarch (Danaus plexippus): Role of an amino acid substitution in the ouabain binding site of $\mathrm{Na}^{+}, \mathrm{K}^{+}$-ATPase. J. Chem. Ecol. 22, 1921-1937. doi: 10.1007/BF02028512

Kelly, C. A., and Bowers, M. D. (2016). Preference and performance of generalist and specialist herbivores on chemically defended host plants. Ecol. Entomol. 41, 308-316. doi: 10.1111/een.12305

Klitzke, C. F., and Trigo, J. R. (2000). New records of pyrrolizidine alkaloid-feeding insects. Hemiptera and Coleoptera on Senecio brasiliensis. Biochem. Syst. Ecol. 28, 313-318. doi: 10.1016/S0305-1978(99)00073-3

Laurent, P., Braekman, J.-C., and Daloze, D. (2005). Insect chemical defense. Top. Curr. Chem. 240, 167-229. doi: 10.1007/b98317

Linde, I., and Wittstock, U. (2011). Insect herbivore counteradaptation to the plant glucosinolates-myrosinase system. Phytochemistry 72, 1566-1575. doi: $10.1016 /$ j.phytochem.2011.01.016

Macel, M. (2011). Attract and deter: a dual role for pyrrolizidine alkaloids in plantinsect interactions. Phytochem. Rev. 10, 75-82. doi: 10.1007/s11101-010-9181-1

Martins, C. H. Z., Cunha, B. P., Solferini, V. N., and Trigo, J. R. (2015). Feeding on host plants with different concentrations and structures of pyrrolizidine alkaloids impacts the chemical defense effectiveness of a specialist herbivore. PLoS ONE 10:e0141480. doi: 10.1371/journal.pone.0141480

Mason, P. A., and Singer, M. S. (2015). Defensive mixology: combining acquired chemicals towards defence. Funct. Ecol. 29, 441-450. doi: 10.1111/1365-2435.12380

Pennisi, E. (2017). How do gut microbes help herbivores) counting the ways. Science 355, 236. doi: 10.1126/science.355.6322.236

Petschenka, G., and Agrawal, A. A. (2016). How herbivores coopt plant defences: natural selection, specialization and sequestration. Curr. Opin. Insect Sci. 14, 17-24. doi: 10.1016/j.cois.2015.12.004

Renwick, J. A. A., and Lopez, K. (1999). Experience-based food consumption by larvae of Pieris rapae: addiction to glucosinolates? Entomol. Exp. Appl. 91, 51-58.

Schmeller, T., El-Shazly, A., and Wink, M. (1997). Allelochemical activities of pyrrolizidine alkaloids: interactions with neuroreceptors and acetylcholine related enzymes. J. Chem. Ecol. 23, 399-416. doi: 10.1023/B:JOEC.0000006367.51215.88

Schneider, D. (1992). 100 years of pheromone research. Naturwissenschaften 79, 241-250. doi: 10.1007/BF01175388

Schneider, D., Boppré, M., Zweig, J., Horsley, S. B., Bell, T. W., Meinwald, J., et al. (1982). Scent organ development in Creatonotos moths: regulation by pyrrolizidine alkaloids. Science 215, 1264-1265. doi: 10.1126/science.215.4537.1264

Schulz, S. (1998). Insect-plant interactions-Metabolism of plant compounds to pheromones and allomones by Lepidoptera and leaf beetles. Eur. J. Org. Chem. 1998, 13-20. doi: 10.1002/(SICI)1099-0690(199801)1998:1<13::AID-EJOC13>3.0.CO;2-R

Schulz, S., Francke, W., Boppré, M., Eisner, T., and Meinwald, J. (1993). Insect pheromone biosynthesis: Stereochemical pathway of hydroxydanaidal production from alkaloidal precursors in Creatonotos transiens 
(Lepidoptera, Arctiidae). Proc. Natl. Acad. Sci. U.S.A. 90, 6834-6838. doi: $10.1073 /$ pnas.90.14.6834

Sime, K. R., Feeny, P. P., and Haribal, M. M. (2000). Sequestration of aristolochic acids by the pipevine swallowtail, Battus philenor (L.): evidence and ecological implications. Chemoecology 10, 169-178. doi: 10.1007/PL00 001819

Trigo, J. R. (2011). Effects of pyrrolizidine alkaloids through different trophic levels. Phytochem. Rev. 10, 83-98. doi: 10.1007/s11101-010-9191-z

Vleugels, R., Verlinden, H., and van den Broeck, J. (2015). Serotonin, serotonin receptors and their action in insects. Neurotransmitter 2:e314. doi: $10.14800 /$ nt.314

von Nickisch-Rosenegk, E., Schneider, D., and Wink, M. (1990). Time-course of pyrrolizidine alkaloid processing in the alkaloid exploiting arctiid moth, Creatonotos transiens. J. Biosci. 45, 881-894.

von Nickisch-Rosenegk, E., and Wink, M. (1993). Sequestration of pyrrolizidine alkaloids in several arctiid moths (Lepidoptera: Arctiidae). J. Chem. Ecol. 19, 1889-1903. doi: 10.1007/BF00983794

Wang, L., Beuerle, T., Timbilla, J., and Pber, D. (2012). Independent recruitment of a flavin-dependent monooxygenase for safe accumulation of sequestered pyrrolizidine alkaloids in grasshoppers and moths. PLoS ONE 7:e31796. doi: 10.1371/journal.pone.0031796

Wink, M. (1988). Plant breeding: importance of plant secondary metabolites for protection against pathogens and herbivores. Theor. Appl. Genet. 75, 225-233. doi: $10.1007 / \mathrm{BF} 00303957$

Wink, M. (1992). "The role of quinolizidine alkaloids in plant insect interactions," in Insect-plant In-teractions, Vol. IV, ed E. A. Bernays (Boca Raton: CRC-Press), 133-169.

Wink, M. (1993). Allelochemical properties and the raison d'etre of alkaloids. Alkaloids 43, 1-118.

Wink, M. (2000). Interference of alkaloids with neuroreceptors and ion channels. Bioact. Nat. Prod. 21, 3-129. doi: 10.1016/S1572-5995(00) 80004-6

Wink, M. (2003). Evolution of secondary metabolites from an ecological and molecular phylogenetic perspective. Phytochemistry 64, 3-19. doi: 10.1016/S0031-9422(03)00300-5

Wink, M. (2008). Evolutionary advantage and molecular modes of action of multicomponent mixtures used in phytomedicine. Curr. Drug Metab. 9, 996-1009. doi: $10.2174 / 138920008786927794$

Wink, M. (2015). Modes of action of herbal medicines and plant secondary metabolites. Medicines 2, 251-286. doi: 10.3390/medicines2030251
Wink, M., and Legal, L. (2001). Evidence for two genetically and chemically defined host races of Tyria jacobaeae (Arctiidae, Lepidoptera). Chemoecology 11, 199-207. doi: 10.1007/PL00001852

Wink, M., Nickisch-Rosenegk von, E., and Schneider, D. (1990). Processing of pyrrolizidine alkaloids and cardenolides in three moths, Syntomis mogadorensis, Syntomeida epilais and Creatonotos transiens. Symposium Biol. Hung. 39, 53-61.

Wink, M., and Schimmer, O. (2010). "Molecular modes of action of defensive secondary metabolites," in Functions and Biotechnology of Plant Secondary Metabolites, ed M. Wink (Oxford: Annual Plant Reviews; Blackwell), 39, $21-161$.

Wink, M., and Schneider, D. (1988). Carrier-mediated uptake of pyrrolizidine alkaloids in larvae of the aposematic and alkaloid exploiting moth, Creatonotos. Naturwissenschaften 75, 524-525. doi: 10.1007/BF00361292

Wink, M., and Schneider, D. (1990). Fate of plant-derived secondary metabolites in three moth species (Syntomis mogadorensis, Syntomeida epilais, and Creatonotos transiens). J Comp. Physiol. B 160, 389-400. doi: $10.1007 / \mathrm{BF} 01075670$

Wink, M., Schneider, D., and Witte, L. (1988). Biosynthesis of pyrrolizidine alkaloid-derived pheromones in the arctiid moth, Creatonotos transiens: Stereochemical conversion of heliotrine. J. Biosci. 43, 737-741.

Yahr, R., Schoch, C. L., and Dentinger, B. T. (2016). Scaling up discovery of hidden diversity in fungi: impacts of barcoding approaches. Philos. Trans. R. Soc. Lond. B Biol. Sci. 371:20150336. doi: 10.1098/rstb.2015.0336

Zagrobelny, M., and Møller, B. L. (2011). Cyanogenic glucosides in the biological warfare between plants and insects: the burnet moth- birdsfoot trefoil model system. Phytochemistry 72, 1585-1592. doi: 10.1016/j.phytochem.2011.02.023

Conflict of Interest Statement: The author declares that the research was conducted in the absence of any commercial or financial relationships that could be construed as a potential conflict of interest.

The reviewer PFM and handling Editor declared their shared affiliation.

Copyright () 2018 Wink. This is an open-access article distributed under the terms of the Creative Commons Attribution License (CC BY). The use, distribution or reproduction in other forums is permitted, provided the original author(s) and the copyright owner are credited and that the original publication in this journal is cited, in accordance with accepted academic practice. No use, distribution or reproduction is permitted which does not comply with these terms. 